\title{
A Benefit of New Costing Methods for the Strategic Management ${ }^{\#}$
}

\author{
Bohuslava KNAPOVÁ*
}

\section{The strategic management of the company}

The strategic management is presented by the group of activities (subprocesses), which are oriented on the adjustment of directions of the other development of the company as the accounting entity. It is the composite order of activities, which have for the aid to optimize the relation among targets and resources of the company and developmental conditions of market possibilities (Král, 2008).

The strategic management delimits the identification of possibilities and the acceptance of the strategic decision connected with the long-term time horizon, for example in the allocation of resources and ways of their using. The focus of the paper reflects questions and problems of the output oriented management in the strategic time horizon.

\section{The task of the strategic management}

The strategic management is inventive process. Top managers formulate and introduce strategies pointing firstly to the achievement of given targets, secondly to the conformity among internal resources of the accounting entity and market environment and thirdly to the securing of the total prosperity and successfulness of the company. Strategic management is the basis of the management on all levels, the starting point of the system of the planning and budgeting and the element, which integrates the activity of managers on various levels of the economic entity.

\# This paper was prepared in the framework of research plan Development of Accounting and Financial Theory and its Application in Practice from Interdisciplinary Point of View (registered number MSM 6138439903).

Ing. Bohuslava Knapová, CSc. - senior lecturer; Department of Managerial Accounting, Faculty of Finance and Accounting, University of Economics, Prague, W. Churchill Sq. 4, 13067 Prague 3, Czech Republic; 〈knapova@vse.cz〉. 
The strategic management pursues by means of the creation and realization of particular strategies. It uses different accesses to the formulation of the strategy. Usually asserted aspect is hierarchic access (Svoboda - Bittner - Svoboda, 2006), which is founded on the determination of the mission, vision, strategic targets and alone strategy.

The mission limits the elementary orientation of the accounting entity, shows the meaning of its existence. It often expresses the relation to particular groups, mainly owners, employees, customers, suppliers and so on.

The vision has the noticeably long-term character. It gives a view about the position of the accounting entity.

Strategic targets of the accounting entity should lead to expected future results. Their adjustment is deduced from the mission and vision of the company. Strategic targets identify the desirable state, which the economic entity tries to achieve by way of its existence and its activities. Targets of the economic entity can be formulated with the various degree of the generality, they can differ in the objective form. The choice of targets and the manner of their fulfillment are influenced and limited by values, which the concrete company accepts. The primary target is the maximization of the entrepreneurial profit for owners of the company.

Relevant starting points for the determination of the strategy come out from results of strategic analysis; it works with various analytic techniques used also for the appraisal of relations among the market environment and the internal organizational and economic structure of the company.

The strategy specifies ways, how to fulfill the mission, vision and targets. It determines the behavior of the accounting entity with needed activities (subprocesses) and the allocation of economic resources, which are necessary for the achievement of ideational intentions. Strategy with its nature represents intentions, which influence the course and development of the company, for example such intentions, which are concerned with the production, its volume and quality, time, potential customers and so on. Strategies have to be directed on the creation of methods, instruments and measurements, which factual strategies promote. There is mutual relation between factual strategies and strategies of the management. 
The formulation of the mission, vision, targets and strategy requires analyze and evaluate the great volume of information characterizing not only the accounting entity and its particular activities (subprocesses), but also its environment, which surrounds it. This process needs the systematic access, including the identification and analysis of external factors, which have the influence on the accounting entity, and their confrontation with economic resources of this chosen accounting entity under conditions of the dynamics of the environment, uncertainty and certain risk. The strategic management must be continual process, which reacts on changes of the market environment by the fitting of the entrepreneurial process.

\section{Strategies of the company and their system}

Strategy is the indispensable instrument of the surface of the accounting entity in the competitive environment, even the instrument of its prosperity. The substantial task of the strategy is to prepare the every accounting entity on all situations, which can come in the next future with the great probability. The presumption is markedly influenced by the uncertainty, which "accompanies" the future development. That's why the significant role has the ability of the foresight.

It is possible to see the strategy from some aspects, which reciprocally relate to each other, like:

- the process,

- the quanta of activities (i.e. subprocesses),

- the component with the relation on the environment.

The strategy permanently is developed as a process in consideration of company strategic targets.

Targets of the accounting unit are often presented as economic characteristics (for example revenues, profits, returnability and so on), but can be focused also on the social area (publicly beneficial actions, sponsorship, creation of the image of the company and so on) mainly in cases, if the company is dependent on more intensive turnover of human resources (Brandon - Drtina, 1997). 
Desirable targets should fulfill certain criterions, which are often marked as the method "SMART" (Petřík, 2005); the clarification of criterions appears subsequently:

- stimulating,

- measurable,

- acceptable,

- realistic,

- timed.

The strategy leads to the ensurance of the harmony among internal company resources and market environment and to the prospering position of the accounting entity successful in its business.

There is the hierarchic system of company strategies (Sedláčková Buchta, 2006) giving one strategy to other strategy. The entrepreneurial strategy of the company is considered to the top strategy, which determines the basic orientation in the business, i. e. indicates the way of the business.

There are many commercial strategies simultaneously with the top strategy. They have effort to report as soon as possible the highest amount of the entrepreneurial profit. So-called functional strategies are located on the lowest level, for example marketing strategy, strategy of information systems and technologies, production strategies, financial strategies, strategies of human resources and other ones. Nevertheless they can influence and influence the top strategy of the business.

\section{Responsibility for strategic decisions}

The process of the creation of strategies and their realization belong to relevant tasks of the top management. It has privileged and nontransferable responsibility. The top management can't delay the responsibility for the strategic management so that delegate anybody other to do the competent decision.

The manager as a person or group of managers must always have the responsibility for the executed strategic decision. It is necessary to divide managerial decisions as individual or team decisions. The manager makes individual decisions on the certain level of the management. These decisions are ones with the strictly addressed responsibility of the 
concrete person. Such individual decisions are usually made quicker, but can have considerably subjective character. On the other side team decisions are connected with the collective responsibility. They are made mostly with the less addressed responsibility of the concrete person for the decision. Their acceptance is unquestionably more prolonged in certain cases, however these decisions have often more objective character.

\section{The output oriented management of the entrepreneurial process}

The output oriented management in sequence on the responsibility management and process management represents one of traditional accesses to the cost management of the every company (Drury, 2002).

Costings as instruments of the value management serve as information support for the output oriented management.

Costings show, how to assign or ascertain costs, profit, margin, price and other value categories on the output unit (product, semi-finished product, service), on some subprocess or its part (for example operation, which is necessary to make in connection with its realization), on the investment action or other natural output sold to external customers or given for the internal using to other responsibility centers (Knapová, 2007).

The method of the costing means such view point, which shows, how costs and other value categories are assigned or ascertained on the natural output unit. The method of the costing depends on the determination of the costing object, on the cost structure of the costing unit and on methods of the cost allocation to the costing object.

All kinds of final outputs of the entrepreneurial process are considered for the costing object. The costing unit and the costing volume must be determined, too. The costing unit presents the concrete output unit (specified by quantity, time, kind, quality or other way), which assigns or ascertains costs and other value categories. The concrete number of costing units creates the costing volume, for which total costs are assigned or ascertained. 
The structure of various kinds of costings is given by individual conditions of each company in connection with important managerial decisions; appropriate costings solve their tasks in specific items of costs and other value categories.

\section{The strategic oriented management of product costs}

This style of the cost management appears namely in the stage of the research, development, constructional and technological preparation of new or innovated products, when relevant decisions come and concern of parameters of the product and manner of its production; simultaneously it is decided also about future costs of the product. It is evident, that the substantial amount of costs (nearly 85-90\%) connected with new products, arises in the consequence of decisions made in pre-production stages.

Just the possibility of the management of costs in this stage became by the stimulus for the development of new instruments of the management. There are only limited possibilities of the cost management in the stage of the own production, because the most of costs are so called sunk costs or directly invoked costs by parameters and "decided" manner of the production of products. Therefore the operative management of the creation of new or innovated product is oriented "only" on the keeping of the economy of costs.

\section{Target costing}

The target costing is oriented first of all on the management of product costs in pre-production stages and is used to the achievement of the lowest future costs on the product.

The assignment of the target costing is connected with the activity, when it is necessary to verify all possible thoughts of the cost reduction in the stage of the research, development and preparation of the new or innovated product. The design of the product, which fulfills requirements and wishes of customers and secures the required profit to the company by means its price, should be the result of this activity.

The target costing shows new possibilities for the using of costings in the management. There are some dangers for its application. The target 
costing has the effort to reduce product costs however it is not possible to exceed the certain cross, when the reduction of costs incurs the reduction of the quality, the deterioration of work conditions and performance. The reduction of costs brings the positive effect for the restriction of the waste, the elimination of unnecessary and unproductive subprocesses.

Information of the target costing must be used "sensitively". This costing constructed before the beginning of the production is relatively imprecise costing. Mistakes can come both with the estimate of the target price and with the assignment of costs.

The target price can be assigned as too high price and the market doesn't accept it. Then the company can not reach of the required effect and must reduce the target price. There are greater risks in the area of costs. Some costs can be forgotten or other possibilities of savings can be shown during the production. The effort to reach of target costs can extend the whole research and development, too. Thereby the risk is increased, that the target price will not be valid, prices of particular inputs will be changed and so on. Simultaneously total costs on the research and development will be increased and such question is logic, if means given on the research and development will be returned in higher profit in the future.

Although the target costing doesn't mean the fault in the field of costings, neither doesn't solve traditional problems connected for instance with the allocation first of all fixed costs to costings, we see its benefit in the change of the process from the customer to the own production and then in the change of the management of costs in pre-production stages.

\section{Life cycle costing}

The life cycle costing is other new instrument for the management of costs. Firstly, this costing estimates product costs, which arise during its whole life cycle. It comprises wider view on product costs; it consists (except costs arising in connection with the production, sale and administrative) also of costs from the pre-production stage (costs on the research and development, the constructional and technological preparation of the production), costs connected with the finishing of the production cycle and other costs, which are not in operative and plan costings. Secondly, the life cycle costing enables also to see changes of 
the product price and changes of costs on the product during the whole life cycle of the product.

Shorter life cycle of the product and the growth of costs connected with the preparation of the new or innovated product were by the reason for the development of this costing access. The comparison of the price or revenues from sale of the given product and costs arising in the period of the production and sale doesn't suffice to the evaluation of the profitability of products, but it is necessary to take account of costs from the pre-production stage, too.

It is possible to assign the life cycle costing before the beginning of the production process, during of the life cycle and at the end of the life cycle. The life cycle costing, assigned before the beginning of the production process together with the target costing, has the main significance for the strategic management. Just in the pre-production stage we can take the certain precaution in consideration of the future development of costs and revenues or we can decide, if the product will be given to the production program.

The assignment of the life cycle costing before the beginning of the production start from following factors (Šoljaková, 2003):

- the duration of the life cycle of the product,

- the prediction of the sale volume for the whole life cycle,

- the presupposed development of the price,

- the prediction of total costs connected with the product.

The life cycle costing is also used for the evaluation of costs in preproduction stages. Costs on the research and development have the character of investment expenses and it is possible to use all methods for the evaluation of their effectiveness, for instance the net present value, index of the return and so on.

\section{Conclusions}

The top management through the strategic management integrates the entrepreneurial process of the accounting entity into one whole. It creates and ascertains system relations among particular company activities (subprocesses) and centers in consideration of the acquirement of the prosperity and successfulness of the company. The strategic management 
includes decisions about new nonstandard processes, events and situations, that's why requires invention accesses. The process of the strategic management runs under conditions of the permanently greater uncertainty. The strategic management also puts the emphasis on such substantial features, which are formulated in the field, where the strategic management has achieved of the largest fulfillment and development. The strategic management and strategies in this field are connected with the most important decisions, i. e. with the conceptual management and with decisions, which have the relation to long-term time horizon, i. e. with long-term management. The Czech practice must pay attention to the mentioned reality.

The benefit of new costing methods for the strategic management, i. e. using of the target costing and life cycle costing, consists in the orientation on a customer, in the management of costs during the whole life cycle of the new or innovated product and also in the taking account of changes of costs and prices (including costs on the research and development) and in the effort to emphasize attributes, costs, the price of the introduced product or service and the possibility of the realization of the final product on the market.

The target costing is used in pre-production stages and its task is to reach such costs of a new or innovated product in the period before the beginning of the production, when the required profit will be secured.

The life cycle costing judges costs on the product for whole its life cycle, including costs on the research and development, the introducing of the production, marketing costs and costs, which are connected with the finishing of the production; it respects also changes of prices during the life cycle for the measurement of the effectiveness of the new or innovated product.

Two mentioned methods comprise such new tendency, which is typical for the strategic oriented management of products both under conditions of existing great corporations and middle-size companies.

\section{References}

[1] Brandon, Ch. - Drtina, R. (1997): Management Accounting: Strategy and Control. New York, McGraw-Hill, 1997. 
Knapová, B.: A Benefit of New Costing Methods for the Strategic Management.

[2] Drury, J. (2002): Management and Cost Accounting. London, Chapman and Hall, 2002.

[3] Knapová, B. (2007): Output Oriented Management and Its Information Support. European Financial and Accounting Journal, 2007, vol. 2, no. 3-4, pp. 27-33.

[4] Král, B. et al. (2008): Management Accounting. Praha, Management Press, 2008.

[5] Petřík, T. (2005): Economic and Financial Management of a Firm. Praha, Grada Publishing, 2005.

[6] Sedláčková, H. - Buchta, K. (2006): Strategic Analysis. Praha, C. H. Beck, 2006.

[7] Svoboda, E. - Bittner, L. - Svoboda, P. (2006): Modern Accesses in the Management of Enterprises in the New Entrepreneurial Environment. Praha, Professional Publishing, 2006.

[8] Šoljaková, L. (2003): Management Accounting for the Strategic Management. Praha, Management Press, 2003. 


\title{
A Benefit of New Costing Methods for the Strategic Management
}

\author{
Bohuslava KNAPOVÁ
}

\begin{abstract}
Strategic managerial decisions have the great influence on the growing performance of the company as an accounting entity and the successfulness in its business today. Managerial decisions on the strategic level of the management are concerned with the existing internal organizational and economic, responsibility structure of the accounting entity, which must create own strategy system in order to prosper under conditions of the external competitive environment. The strategic management is the conceptual and long-term starting point of the complete management. New costing methods, i. e. using of the target costing and life cycle costing, belong to the areas of the output oriented management and are applied in the strategic (long-term) management of product costs.
\end{abstract}

Key words: Strategic management; Output oriented management; Managerial decisions; Strategy system; Target costing; Life cycle costing.

JEL classification: M41. 